\title{
Mayoral Leadership in Shaping Urban Beautification in Surabaya and Aspects Influencing Its Capacity
}

Faruq Ibnul Haqi1,2

1. School of Creative, University of South Australia, Adelaide, Australia faruq.haqi@mymail.unisa.edu.au

2. Department of Architecture, Universitas Islam Negeri Sunan Ampel, Surabaya, Indonesia

\section{Sri Tuntung Pandangwati ${ }^{3,4}$}

3. Department of Urban and Regional Planning, Universitas Gadjah Mada, Yogyakarta, Indonesia

4. School of Global Urban and Social Studies, Royal Melbourne Institute of Technology, Melbourne, Australia s3636494@student.rmit.edu.au

\begin{abstract}
Abstrak
Kepemimpinan memiliki arti yang sangat luas karena merupakan studi lapangan yang terdiri dari berbagai dimensi yang berbeda seperti psikologi, manajemen, organisasi dan politik. Di sisi lain, kajian tentang peran kepemimpinan dalam isu pembangunan perkotaan masih relatif langka, terutama dalam konteks negara berkembang. Literatur menunjukkan bahwa bagaimana pemerintah daerah di bawah walikota sebagai posisi tertinggi disebuah kota dalam memprioritaskan pembangunan perkotaan sangat dipengaruhi oleh normanorma sosial budaya dan gaya kepemimpinan. Oleh karena itu, peran kepemimpinan walikota sangat penting terkait intervensi pemerintah daerah untuk mempromosikan kecantikan Kota di Indonesia. Tidak dapat dipungkiri bahwa kepemimpinan merupakan aspek penting dalam tata kelola perkotaan. Mengambil studi kasus di Surabaya, bukti menunjukkan bahwa kepemimpinan memainkan peran penting dalam tata kelola perkotaan terutama dalam hal proses fasilitasi dan konsultasi. Berdasarkan analisis literatur dokumen yang relevan dan wawancara dengan pengambil keputusan di Surabaya, temuan menunjukkan bahwa kualitas kepemimpinan walikota telah memainkan peran penting dalam meningkatkan keindahan bentuk perkotaan di Surabaya sebagai hasil dari proses desain perkotaan. Mekanisme yang mendasari peran ini antara lain bahwa walikota memiliki pemahaman yang baik tentang desain perkotaan dan telah mampu turun tangan untuk menuntut desain perkotaan yang baik sebagai sebuah kebijakan dan memiliki kedudukan untuk dapat mendekati pejabat dan anggota masyarakat dalam proses perkotaan yang cantik. Kualitas kepemimpinan walikota berperan penting dalam mewujudkan keindahan kota Surabaya yang lebih baik. Walikota yang memiliki pemahaman yang luas tentang desain perkotaan merupakan sebuah keuntungan bagi pemerintah daerah.
\end{abstract}

Kata kunci: kepemimpinan walikota, keindahan kota, desain kota, pemerintahan kota

\begin{abstract}
Leadership has an expansive meaning because it is a field study that comprises several different dimensions such as psychology, management, organization, and politics. On the other hand, the study of leadership's role on urban development issues is still relatively scarce, especially in developing countries. The literature shows that local governments under the mayor as the highest-ranking position of municipal prioritise urban development is very much a function of socio-cultural norms and leadership styles. Therefore, mayoral leadership is vital regarding local government interventions to promote urban beautification in Indonesia. It is undeniable that leadership is a significant aspect of urban governance. Taking a case study in Surabaya, evidence shows that leadership plays important roles in urban governance,
\end{abstract}


especially in facilitating and advising processes. Drawing on analysis of relevant documents, literature, and interviews with key decision-makers in Surabaya, the findings indicate that the quality of mayoral leadership has played a vital role in enhancing the beautification of urban form in Surabaya as a result of the urban design process. The mechanisms underlying this role include that the mayor has a sound understanding of the urban design and has been able to intervene to insist on good urban design as policy and has the standing to approach officials and community members on the urban beautification process. The quality of mayoral leadership has played a vital role in shaping the better urban beautification of Surabaya. A Mayor who has a wide-ranging grasp of urban design has advantages for the local government.

Keywords: mayoral leadership, urban beautification, urban design, urban governance

Received: 2020-09-02 | Accepted: 2021-02-12 | DOI: 10.29080/eija.v6i2.1010| Page: 91-104

EMARA: Indonesian Journal of Architecture
http://jurnalsaintek.uinsby.ac.id/index.php/EIJA
$\begin{aligned} & \text { CC) Shis article is open access distributed under the terms of the Creative Commons Attribution } \\ & \text { ShareAlike 4.0 International License, which permits unrestricted use, distribution, and } \\ & \text { reproduction in any medium provided the original work is properly cited. }\end{aligned}$

\section{Introduction}

Cities have grown in all countries and the need for better planning and management of urban environments has become more urgent in recent decades. A planned and well-designed city has an important benefit for the population. Sustainability in planning and urban development has become an essential guiding principles among professionals and academics globally, commonly being applied to urban design elements (Childs, 2010). Applying urban design elements to urban development processes is a reflection of the high value that is placed on modern cities. Whether a good urban design is achieved is a measure of the effectiveness of the planning process, and it also indicates the extent of community leaders' support for urban design.

Urban designs are a response to the specific problems of each city. Designs and plans indicate the need for city managers and planners to be responsible for matters regarding the environment and its inhabitants, the aim being to foster cities as friendly environments and attractive as an effort to implement urban beautification. Many challenges are faced by Indonesian cities as they seek to implement urban design policies in the process of urban development and urban planning, and they must also maintain the elements of urban design that already exist. City planners face numerous competing interests at both national and local levels, and there is the issue of overlapping regulations and competition for resources so that local governments are having difficulty implementing any worthwhile urban designs. A key figure in this whole subject is the mayor who is in a strong leadership position and able to demand and implement a good urban design.

Madanipour (2006) stated that cities face many challenges when seeking to implement the urban design to address their respective urban issues. Metropolitan cities have many differences, but they also have many problems in common (such as congestion and pollution), but one common issue is the lack of strong leadership to motivate and implement urban design within their policies. This condition is particularly evident in developing countries, one of which is in Indonesia which has more than 514 cities. 
Leadership has a broad definition because it is a field study that comprises several dimensions such as psychology, management, organization, and politics (John \& Cole, 1999). Furthermore, leadership is a popular and academic field of study with an extensive range of definitions involving practical issues and theories (Couto, 2010). Couto (2010) defines leadership as the resources of individuals that enables them to build relationships in a particular context that usually a complex system. These definitions represent that leadership is a process that consists of three aspects: leader, follower and context. In terms of urban governance, leadership is defined as 'governing capacity' (John \& Cole, 1999). In this context, leadership is usually related to local governance, municipal leaders, and the political system (Gissendanner, 2004; Haus \& Erling Klausen, 2011; Sweeting, 2002). However, the discussion of leadership in urban governance issues is still relatively limited, especially about leaders' role in governing urban areas (Satterthwaite, 2009). Therefore, this paper discusses broadly the three components of leadership instead of focusing on a specific aspect of leadership.

Leadership has an increasingly important role in urban governance (Dávila, 2009; Haus \& Erling Klausen, 2011; Irazábal, 2017; John \& Cole, 1999). Some scholars argue that leadership and community engagement are critical factors for successfully implementing urban planning (Haus \& Erling Klausen, 2011; Irazábal, 2017). Moreover, local political leaders have a significant role in accommodating local communities to participate in collective action (John \& Cole, 1999). Additionally, city mayors have played a critical role in generating a better future for their citizens and the municipalities they lead (Dávila, 2009).

Responding to the increasingly crucial urban governance issue, this article aims to answer two main questions. The first one is what leadership roles in urban governance and what circumstances affect the quality of leadership in urban governance. The second one is the linkages between urban leadership and urban beautification. Understanding what situation forms a good leader is essential for urban planning because good planning will be useless without support from a good leader in urban governance (Irazábal, 2017). Understanding urban leadership's role in establishing good urban governance is beneficial to generate more reliable city leaders in the future.

\section{Methods}

The critical research approach adopted in this study is qualitative, and the primary method is a case study. This study draws upon relevant literature that addresses mayoral leadership and urban beautification concepts, emphasizing the City of Surabaya. All participants were interviewed to acquire information on the role of mayoral leadership in influencing urban design principles to enhance urban development. In the interview, they were asked to express their views on their perception of the urban leadership and the roles of mayoral. Other data-gathering methods were contained within the assortment of secondary data, including an analysis of documents, government reports, web pages, and other literature.

The qualitative content analysis method was used to analyze the data that has been collected. Bryman (2007) stated that content analysis delivers technique to control raw data selected more controllable for the analysis and investigate integrally qualitative processes of leadership (Lakshman, 2012). 
This analysis helps the researchers expand a concept and model based on coding, categorizing, and connecting by each element. All data interviews that have been transcribed and categorized were organised, coded, and analyzed with QSR NVivo software.)

\section{Result and Discussions}

Types of leadership in urban governance Urban governance is defined as managing urban areas, including people, resources, and social-economic activities (Kearns \& Paddison, 2000). This process involving different actors with different interests and backgrounds that work together to achieve a shared vision of an urban area (Steele \& MacCallum, 2014) Governance capacity depends not only on institutional issues but also on the leadership issue related to leaders' ability to engage and persuade other individuals (stakeholders) to support particular public policies or projects (Gissendanner, 2004). It is a governing process that requires a relation between various public and private actors and is centered on one particular actor who leads, maintains, and coordinates the workflow in this process (Gianoli, 2010). This relation depicts leadership as one component of urban governance that influences its quality.

Literature defines types of leadership that emerge in urban governance. There are many typologies developed in the field study of leadership. However, these typologies can be combined into one matrix (see table 1) (John \& Cole, 1999). This matrix shows leadership types in terms of their character and how strong their power in managing change and complex conditions emerged in contemporary urban governance. In general, leadership has two characters: responsive and directive. Responsive means lack intervention in the rapidly changing policy and increasingly complex policy-making process. Directive means the ability to control and direct a change in urban governance.

Table 1. Typology of leadership in urban governance

\begin{tabular}{|c|c|c|c|}
\hline & & \multicolumn{2}{|c|}{ Type of power } \\
\hline & & Power to & Power over \\
\hline \multirow{2}{*}{$\begin{array}{l}\text { Type } \\
\text { of } \\
\text { action }\end{array}$} & $\begin{array}{l}\text { Respons } \\
\text { ive }\end{array}$ & $\begin{array}{c}\text { Consensual } \\
\text { Facilitator }\end{array}$ & Caretaker \\
\hline & Directive & Visionary & City Boss \\
\hline
\end{tabular}

Source:(John \& Cole, 1999)

John \& Cole (1999) suggest four leadership types in urban governance (see table 2). Firstly, a caretaker is one type of leadership that finds it hard to adapt to rapid change and the policy-making process's complexity. It shows that this is the weakest type of leadership. Secondly, the consensual facilitator is far more adaptable than the caretaker, although it is still weak in directing change in the policymaking process. This type of leadership considers the importance of networking and partnership to manage change in the urban system. Thirdly, a city boss is a strong leader, but they cannot make a sustainable change in the urban policymaking system. Although urban management strategies developed by the city boss cannot stay long after the leader leave his/her office. Strong leaders made significant innovations during their work, but some of these innovations were not sustained (Satterthwaite, 2009). The last one is visionary leadership, which combines strong characteristics of leadership. It is directive because it adapts the change and directs and makes innovation to address the urban policymaking system's complexity and solve urban issues. Moreover, it has a strong power that can make a significant change to the system so that their innovations could last for many years after the leadership period over. 
Table 2. Types of leadership emerge in different kinds of the cultural system

\begin{tabular}{cc}
\hline $\begin{array}{c}\text { Internal focus and } \\
\text { integration }\end{array}$ & $\begin{array}{c}\text { External focus and } \\
\text { differentiation }\end{array}$ \\
\hline CLAN: & Adhocracy: \\
Facilitator and & Innovator and visionary \\
Mentor & Market: \\
\hline Hierarchy: & Competitor and \\
Monitor and & producer \\
coordinator &
\end{tabular}

Source: (John \& Cole, 1999)

Another typology of leadership is established based on the culture influencing the urban policy-making system. Four types of leadership emerge in four different urban cultural systems (Martin \& Simons, 2002). Clan culture, where community and society's value is robust, tends to generate facilitative and advising leadership (facilitator and mentor). This type of leadership focuses on people and involves them formulating solutions and making decisions. In the CLAN of leadership type, leaders have a vital position in establishing participatory planning. Another sort of leadership generated by adhocracy culture. This cultural setting, which has a relatively flexible structure and lack of formal structure, tends to create innovative and visionary leadership. This type of leader is future-oriented, and it can adapt to increasingly complex urban problems by creating innovations. The typical action done by this type of leadership is the strategic direction to improve the existing condition.

In contrast, a hierarchy culture with a very formal structure tends to produce a monitor and coordinator. This type of leadership influences controlling the process of governance and keeping its stability. Maintaining structure and strict management of work are the fundamental principles of this leadership. Lastly, competitive and productive leadership are likely to be found in the market culture. A competitive situation creates leadership that focuses on productivity, goals, and targets.

These two kinds of typology look similar, but they use different approaches. John and Cole (1999) implicitly define which type of leadership is the most effective in dealing with contemporary urban problems. It is depicted by how he determines how powerful each leadership type is. Martin and Simons (2002) consider the broader context of urban governance and use cultural aspects to determine each type of leadership's success. Each type of leadership's effectiveness is based on where it is implemented. Each type of leadership in this typology looks contrast, but they are not opposites because they work in different cultural systems. Leadership does not just talk about leaders but also its follower and social-cultural context (Couto, 2010). Furthermore, this typology helps develop an understanding of different leadership needs and why various leadership kinds emerge in a contemporary urban context.

A more recent study suggests two leadership types in the current urban governance context: place leadership and network governance (Mullins \& Bortel, 2010). Place leadership is a type of leadership in urban governance concentrating on places, local contexts, and partnerships. Network governance is a type of leadership that aims to create a common interest in order to bring together different actors with various backgrounds. These leadership types emerged because there is a shift from urban government to governance nowadays. These two types of leadership have a shared approach in networking, but place leadership has a relatively more specific focus on spatial context (place). This study suggests that leadership that 
can establish networking is a type of leadership needed to address contemporary urban problems.

Overall, there are many types of leadership found in the urban governance context. Each type has a different characteristic in running the governance process, and they work in different kinds of the urban governance system. John and Cole (1999) suggest that facilitator and visionary leadership are more effective than any other leadership kind. However, Martin \& Simons (2002) argue that a certain kind of leadership's effectiveness relies on its urban governance system. Mullins \& Bortel (2010) also indicate that changes in the present-day urban governance system influence the emergence of new leadership types such as place leadership and network governance. Therefore, understanding the context is essential in defining which type of leadership is needed.

\section{The type of leadership needed in addressing urban issues)}

Even though leadership is a process involving leader, follower and occur in a particular situation (Couto, 2010), this process is still centered on a single dominant actor called a leader (Gianoli, 2010). In this section, leaders' role in the urban governance system and their approaches or characteristics in addressing the present-day urban problem is examined. Leaders can come from different actors involved in the urban governance process. Some literature discusses the role of the mayor as the most significant actor in urban governance (Dávila, 2009; Gianoli, 2010; John \& Cole, 1999; Satterthwaite, 2009), and some of them compare different types of urban leaders (Greasley \& Stoker, 2008; Martin \& Simons, 2002). Several other pieces of literature discuss how important the role of leadership and a particular figure in creating good urban governance (Barber \& Eastaway, 2010; Mullins \& Bortel, 2010; Rondinelli \& Heffron, 2009).

Leadership became an important issue in urban governance in Europe and Latin America since the decentralization reform in the late 1980s. Mayors became an important figure who has a critical role in directing the local policy-making process (Dávila, 2009; John \& Cole, 1999). However, Latin America gains more positive outcomes from this reform than European countries. Gissendanner (2004) and John and Cole (1999) assert that this decentralization reform in Europe was a challenge because the urban governance system has become more complex. On the other hand, Dávila (2009) and Satterthwaite (2009) suggest that this reform, especially the presence of a directly elected Mayor, gave more benefit for Latin American citizens because mayors tend to pay more in this system attention to the poor. This system requires moral commitment for the directly elected leaders.

In terms of decentralization, facilitative leadership is the most effective leadership type in the decentralization era for European and Latin American contexts. In Latin America, mayors are responsible for dealing with many problems related to improving the citizens' well-being, especially poverty, and coordinating different stakeholders involved in development (Satterthwaite, 2009). In this context, Dávila (2009); Gissendanner (2004); Satterthwaite (2009) suggest that a leader who can create frequent interaction with the citizens is needed. This type of leader is defined as facilitative leadership (Martin \& Simons, 2002). European countries also face a similar challenge in terms of decentralization. The urban governance system became much more complicated during decentralization. 
Agencies are much more competitive; the governance system is fragmented, citizens and media are more critical (Greasley \& Stoker, 2008). In this context, decentralization needs a robust, innovative, and facilitative leadership to direct the urban decision-making process (Greasley \& Stoker, 2008; John \& Cole, 1999).

Facilitative leadership is also needed in the deindustrialization context. Gissendanner (2004) discusses municipal leaders' role in improving the cities' governance capacity and strategic capacity in the deindustrialization era. Two German cities' (Dortmund and Augsburg) responses to deindustrialization are analyzed as two examples representing attempts done by many other cities in addressing socio-economic problems such as unemployment. Both Dortmund and Augsburg faced a crisis in the deindustrialization era and have similar institutional systems. However, the study asserts that the mayor's leadership in Dortmund was more successful than Augsburg. This mayor could utilize concealed resources such as aid, political system, consensus, partnership, and momentum to improve socio-economic conditions during the crisis.

Additionally, Dortmund's most exciting aspect of leadership is the power of the relationship between leader and follower. This kind of character is included in facilitative leadership (Martin \& Simons, 2002). So, it is true that the mayor, as the leader, has an essential role in creating improvement, but he did it by working together with other individuals. In this case, successful leadership is not just about a leadership skill of individual but a skill to generate and implement resources to induce other people, especially followers, to support a shared vision.
Another issue faced by many European countries is urban regeneration. Literature suggests that leadership plays a significant role in addressing socioeconomic issues through urban regeneration (Barber \& Eastaway, 2010; Heffron, 2014; Mullins \& van Bortel, 2010). A study conducted by (Heffron, 2014) analyses leadership's role in urban regeneration policy delivery in the UK's financial crisis period. This study suggests that urban regeneration policies need to be delivered by promoting leadership and restructuring the urban governance system. In this case, delivering regeneration policies in a limited fund is possible if supported by strong leadership.

Furthermore, a study conducted by Barber and Eastaway (2010) compares the performance of leaders in Birmingham and Barcelona in addressing the demand for urban regeneration. This study found that Barcelona performs better than Birmingham. Even though these two municipalities have similar top-down types of leadership, Barcelona's governance process has more integration and community engagement than in Birmingham. Another evidence showed the importance of facilitative leadership style in addressing urban problems. Moreover, Mullins and van Bortel (2010) also assert that a successful urban regeneration is supported by a leadership that can engage with an extensive range of actors, including citizens, and implements a democratic and inclusive policy-making process.

Facilitative leadership style is a type of leadership influential in addressing urban problems both in European and Latin American countries. Even though these groups have different problems, facilitative leadership provides effective communication and integration between leaders and followers. In the Latin 
American context, this enables leaders to create proximity to their people to understand better how to assist them in solving poverty and inequality effectively. In European urban regeneration problems, facilitative leadership fosters regeneration policy delivery by encouraging stakeholders to integrate and work together.

\section{Circumstances that form a good leader}

The Municipal leader is an essential political position in urban governance, but this does not guarantee the significance of his/her role in addressing urban problems. Several components affect the quality of leadership, such as institutional and local settings and the leaders' characters (Greasley \& Stoker, 2008; Sweeting, 2002).

In the case of Dortmund and Augsburg, an urban leader's governing capacity is influenced by the presence of leaderfollowers cooperation, ability to create innovation, informal resources, and political culture (Gissendanner, 2004). These two municipalities have institutionally strong leaders during the deindustrialization crisis. They also have party loyalty, friendship, and solidarity in their political culture. However, significant institutional segregation in Augsburg political system became an obstacle for the mayor to create strong leader-follower leadership and generate innovation to improve the city's strategic capacity.

Satterthwaite (2009) suggests that innovative leadership, one aspect influencing good urban governance, is determined by the supportive national system, whether he/she comes from the outside political system, frequent interaction made with followers and whether he/she is elected directly by the citizens. These external and internal factors enable leaders to innovate in the governing process. For example, a mayor who comes from a professional and academic institution has more freedom to innovate than someone who comes from a political party, which usually has a particular interest (Gissendanner, 2004).

Direct election is one aspect that has a positive influence on improving leadership performance in urban governance. Dávila (2009) suggests that directly elected mayors tend to be more responsive to the poor's needs, mostly in Latin American countries. The condition creates morale and commitment the leaders must make readers. A similar thing is suggested in the European context. John and Cole (1999) argue that directly elected mayors can claim a mandate and avoid faction fighting in party organizations. Moreover, a study done by Gianoli (2010) asserts that leadership delivered by a directly elected Mayor in Turin, Italy has a vital role in addressing complex governance systems and creating innovation in the policy-making process. This direct election method has positive impacts on increasing prominence and governance performance of a mayor.

Psychological and personal aspects indeed affect the quality of leadership, but this is also affected by the institutional aspect (Barber \& Eastaway, 2010; Greasley \& Stoker, 2008; John \& Cole, 1999; Sweeting, 2002). The institutional aspect is formal and informal organizations that give the leader formal power and authority (Haus \& Erling Klausen, 2011; Sweeting, 2002). This institutional aspect is like a base that determines how a leader can work and use his/her authority. An excellent institutional arrangement is a structure that delegates much power to the municipal leader to do his/her executive function, and there is no need to share his/her authority with any other organizations (Greasley \& Stoker, 2008). 
Moreover, the constitution is part of the institution that also impacts determining certain types of leadership by requiring a relationship between leaders and followers (Greasley \& Stoker, 2008).

Also, local political culture influences fostering a suitable leadership type (Barber \& Eastaway, 2010; Bochel \& Bochel, 2010; Haus \& Sweeting, 2006). High social capital in a political culture positively impacts fostering collaborative leadership (John \& Cole, 1999). This enables followers and any actors with different interests to work together with the leaders to support their better future. In terms of culture in the planning context, Barber and Eastaway (2010) suggest that community engagement thoroughly implemented in Barcelona creates the strong clan culture in its local planning practice. This fostered strong cooperation between leaders and followers in the urban governance process.

\section{Qualitative content analysis Mayor and local government}

The literature above (in the context of Western) discussed that leadership (aspects influencing its capacity) and governance are the main features of the urban development process. To describe these qualities in the case study of the City of Surabaya, all respondents who are the key player of policymakers volunteered to be interviewed. Most indicated that their responses express both their institutional and personal opinions concerning both aspects in influence urban design policy as one of the strategies of urban beautification in Surabaya.

As a city leader of the local government, the mayor contributes to the urban development process, especially in influencing urban design or planning policy. It indeed that the mayor who has strong leadership and high commitment can make a city more beautiful and able to face the current municipal challenges through urban design strategies (Irvine,
2008). Furthermore, Satterthwaite (2009) argued that the municipal government requires a mayor who understands and knows about city planning. Therefore, the fundamental question 'does mayoral leadership matter in influence urban design/planning policy as one of the strategies in urban beautification in Surabaya?'.

Numerous respondents of this study have answered this question. A senior officer in the environmental board, he states that:

"Another city leaders in Indonesia rarely own it. Usually, their background is politicians, businessmen, economics, artists, etc. Surabaya mayor's background is an architect who influenced the urban development of Surabaya.". (Respondent \#2)

Another view is from a critical policymaker in the department of waste management and parks which mentioned that:

"... Surabaya is lucky to have a high-quality mayor who concerns about the environment and urban development. Our mayor is the 3rd best in the world. I knew that she is an architect". (Respondent \#4)

Another perspective has come from a senior officer in spatial planning who further commented:

"...she was a planner who knows about urban design, so she always intervened directly in guarding all the process. It is one of her commitments to urban design policy". (Respondent \#3)

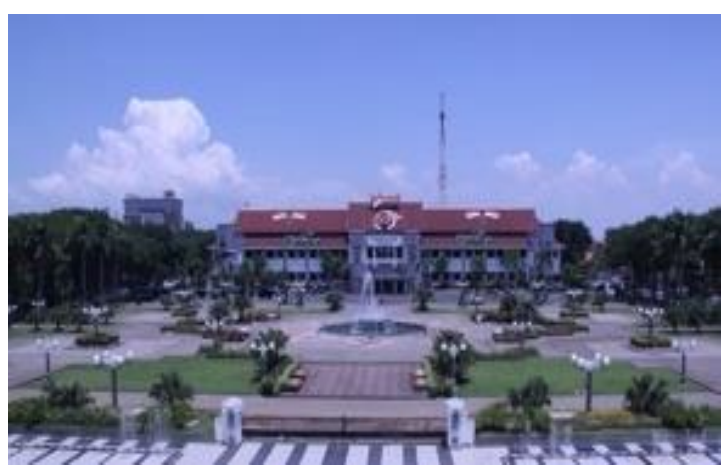

Figure 1. City hall of Surabaya (Source: Authors, 2015)

He also commented regarding the role of the mayor in implement urban design: 
"Before elected as mayor, she served as a government employee in Surabaya, such as Chief of Research and Development, Head of $D K P$, and lastly, she was a Head of Bappeko (Development Planning Agency). Thus, she understands Surabaya's context and how to create an urban form of Surabaya much better through urban design. Simply an example, she placed elements of urban design in front of city hall". (Respondent \#3)

From these responses, it is understandable that the respondents had been aware that the Mayor of Surabaya has a planner background. Mayor's experience includes following short courses abroad has a significant influence on employ urban beautification and how to manage the municipality much better. It is extensively acknowledged that a mayor's municipal performance is shaped by their knowledge (Avellaneda, 2009). This has been reinforced by the work of Fiedler (1986), who acknowledged that:

"Cognitive resource theory assumes that more intelligent and knowledgeable leaders make better plans and decisions than do those with less ability and knowledge."

It is indispensable for the city to require a mayor who has exceptional understanding, a high commitment to the urban design policy, and a forwardthinking approach to the environment. It is matching as stated by the senior officer respondent about the commitment of the mayor in the development process Surabaya:

"... In the attendance of businessman forum meeting, the mayor said that she has a commitment to build the city of Surabaya based on ecology approach". (Respondent \#3)

He further commented:

"...she was a planner who knows about urban design, so she always intervened directly in guarding all the process. It is one of her commitments to urban design policy". (Respondent \#3)

It can be concluded that the quality of mayoral leadership has played a vital role in shaping urban beautification in Surabaya through urban design. A Mayor who has a wide-ranging understanding of urban design is advantageous for the local government. With the right leadership attitude, she can make the urban design a policy and approach the community mediated by urban design. This is in line with Haqi's (2016) work, which stated that the urban policy focused on local action and community empowerment involving multiple agencies and stakeholders to achieve sustainable communities and social sustainability. The mayoral leadership and public involvement together can affect legitimate and operational policy-making in the context of urban governance (Haus \& Erling Klausen, 2011)

\section{The links between mayor leadership and urban beautification}

From the findings discussed previously, the role of the leadership of the mayor has been recognized by all respondents as the primary attribute in the urban design process to achieve urban beautification in Surabaya. As a municipality government leader, the mayor impacts the urban development process, especially in influencing urban design. Irvine (2008) found that a mayor who has strong leadership can create a city more attractive and face the current municipal challenges through urban design strategies. Irvine also added that a mayor who has strong leadership and high commitment could make a city more beautiful and face the current municipal challenges.

This is in line with one of the critical policymakers of Surabaya who was explained his view on what has been done by the mayor in promoting urban design as one of the strategies to achieve urban beautification in Surabaya as follows:

"Mayor is very concerned about the urban issues in Surabaya. One of her achievements is reforming the dead-space that is derelict and dirty to be superb of urban open space, namely Bungkul Park, which won the "United Nations Asian Townscape Award 
2013". In this place, she (Mayor) applied the principles of urban design in the planning process, in which the community can utilize all activities and facilities". (Respondent \#1

He further comments that:

"Her expectations are high in applying urban design in Surabaya. She compares Surabaya to other metropolitans like London, New York, Seoul, and others. To achieve these targets, the mayor engages some stakeholders to assist the program (urban beautification) in Surabaya; one of them is through Corporate Social Responsibility (CSR). It is intended to save the budget". (Respondent \#1)

In the case of Surabaya, it is recognizable that the mayor's background is a planner, so the mayor can be addressing urban development issues through urban design to shape urban beautification. This is recognized by Avellaneda (2009), who stated that their knowledge forms the mayor's performance in the municipal.

Furthermore, Haqi \& Pieters (2019) found that Surabaya mayor has played a vital role in promoting urban design as one of the urban policies. As indicated by Heath et al. (2006), the municipal requires the effectiveness of urban policy based on the ecological approach for promoting urban policy. They also argued that the mayor should have policy interventions to promote urban design as an excellent policy to achieve better urban beautification. This is more worthwhile rather than concentrating on shifting the behavior of people. However, in the implementation of urban design, the local government needs collaboration from all parties, such as stakeholders, the community, and NGOs, to achieve them (Purbani, 2017).

What is more, the role of leadership in influencing urban design in the urban beautification process has been acknowledged as a vital attribute of the mayor. Then, how are the links between leadership and urban beautification? Urban design policies that intervene by the mayor who has strong leadership have participated in urban beautification as a part of the urban development process in Surabaya. By providing more public space and urban design attributes inside. Then, urban street trees also reduce pollution from vehicles that are good for the health and environment (figure2). As such, as stated by Haqi (2016) that the urban development process will be easily visible with a 'high' environmental quality)

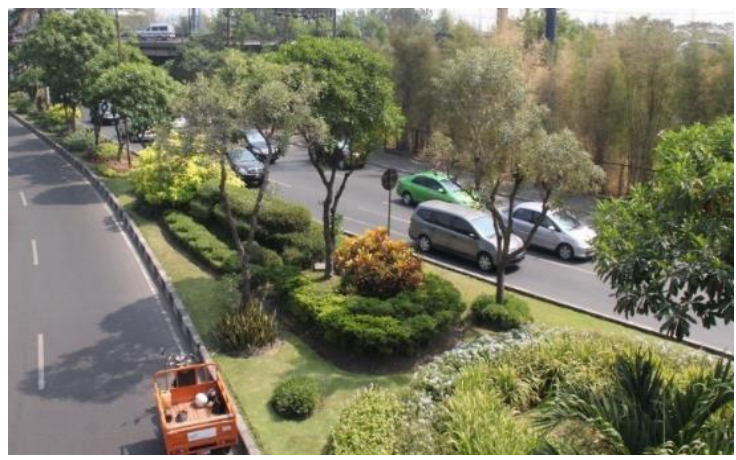

Figure 2. urban street (Source: authors, 2015)

\section{Conclusion}

It is undeniable that leadership is a significant aspect of urban governance. Shreds of evidence show that leadership plays an essential role in urban governance, especially in facilitating and advising processes. Several studies in the literature suggest that leadership's role in establishing physical proximity with its followers and integrating different interests is critical in determining the urban governance process's success. Furthermore, several circumstances influence leadership performance, including external and internal aspects. It is affected by the leaders' characteristics and several external factors such as the constitution, institutional system, and local political culture where it is implemented. Therefore, improving 
leadership performance in urban governance can create a more facilitative type of leadership. Additionally, improving external factors can be done by establishing a constitution that requires more community engagement, an institution that supports innovations, and creates a local political culture with a strong common interest.

Drawing on the interview's key findings and based on the qualitative analysis approach, this study has found a close relationship between mayoral leadership and the urban beautification process. Based on Surabaya's case in this study, the quality of leadership of a mayor who has a background as a planner or architect is convincingly beneficial for municipalities. This is because the mayor, as the highest-ranking position in the municipal, understands how to shape the city more beautiful, comfort and active for the community so that the mayor could promote urban design as one of the good 'tool' policies in achieving better urban beautification in Surabaya.

\section{Disclosure statement}

No potential conflict of interest was reported by the author(s).

\section{Acknowledgment}

The authors thank the anonymous reviewers and the editors for their constructive comments on this paper.

\section{References}

Avellaneda, C. N. (2009). Municipal Performance: Does Mayoral Quality Matter? Journal of Public Administration Research and Theory, 19(2), 285-312. https://doi.org/10.1093/jopart/ mun001

Barber, A., \& Eastaway, M. P. (2010). Leadership challenges in the inner city: Planning for sustainable regeneration in Birmingham and Barcelona. Policy Studies, 31(4), 393-411. https://doi.org/10.1080/014428 71003723309

Bochel, H., \& Bochel, C. (2010). Local Political Leadership and the Modernisation of Local Government. Local Government Studies, 36(6), 723-737. https://doi.org/10.1080/030039 30.2010 .523199

Bryman, A. (2007). Qualitative Research 2. SAGE Publications.

Childs, M. C. (2010). A Spectrum of Urban Design Roles. Journal of Urban Design, 15(1), 1-19. https://doi.org/10.1080/135748 00903429357

Couto, R. A. (2010). Political and Civic Leadership: A Reference Handbook. SAGE Publications.

Dávila, J. D. (2009). Being a mayor: The view from four Colombian cities. Environment and Urbanization, 21(1), 37-57. https://doi.org/10.1177/095624 7809103003

Fiedler, F. E. (1986). The Contribution of Cognitive Resources and Leader Behavior to Organizational Performance1. Journal of Applied Social Psychology, 16(6), 532-548. https://doi.org/10.1111/j.15591816.1986.tb01157.x

Gianoli, A. (2010). Directly elected mayor and effectiveness of strategic city planning: The case of Turin, Italy. Journal of Town \& City Management, 1(2), p186-196. https://web.a.ebscohost.com/abst ract?direct=true \&profile=ehost\&s cope $=$ site \&authtype $=$ crawler\&jrnl $=17569583 \& \mathrm{AN}=87721988 \& \mathrm{~h}=\mathrm{V}$ 1uCmc4zbvb\%2f6cu1zP6D\%2fz4 daZ9vS3udrJOJMDDSL88robzPZ6 QQtXbTQ3Ul7L4iv1y8SaaE9j1BE MPXiaTBvw\%3d\%3d\&crl=c\&resu ltNs=AdminWebAuth\&resultLocal $=$ ErrCrlNotAuth\&crlhashurl=login .aspx $\% 3$ fdirect $\% 3$ dtrue $\% 26$ profil e $\% 3$ dehost $\% 26$ scope $\% 3$ dsite $\% 2$ 6authtype\%3dcrawler\%26jrnl\%3 d17569583\%26AN\%3d87721988 
Gissendanner, S. (2004). Mayors, Governance Coalitions, and Strategic Capacity: Drawing Lessons from Germany for Theories of Urban Governance. Urban Affairs Review, 40(1), 44-77. https://doi.org/10.1177/107808 7404267188

Greasley, S., \& Stoker, G. (2008). Mayors and Urban Governance: Developing a Facilitative Leadership Style. Public Administration Review, 68(4), 722730.

https://doi.org/10.1111/j.15406210.2008.00910.x

Haqi, F. I. (2016). Sustainable Urban Development and Social Sustainability in the Urban Context. EMARA: Indonesian Journal of Architecture, 2(1), 2126.

https://doi.org/10.29080/eija.v2i 1.15

Haqi, F. I., \& Pieters, J. (2019). The Role of Leadership Influencing the Health Equality Through Urban Design in the City of Surabaya, Indonesia. International Journal of Engineering \& Technology, 8(1.9), 434-438.

https://doi.org/10.14419/ijet.v8i 1.9.26703

Haus, M., \& Erling Klausen, J. (2011). Urban Leadership and Community Involvement: Ingredients for Good Governance? Urban Affairs Review, 47(2), 256-279. https://doi.org/10.1177/107808 7410388867

Haus, M., \& Sweeting, D. (2006). Local Democracy and Political Leadership: Drawing a Map. Political Studies, 54(2), 267-288. https://doi.org/10.1111/j.14679248.2006.00605.x

Heath, G. W., Brownson, R. C., Kruger, J., Miles, R., Powell, K. E., \& Ramsey, L. T. (2006). The Effectiveness of Urban Design and Land Use and Transport Policies and Practices to Increase Physical Activity: A
Systematic Review. Journal of Physical Activity and Health, 3(s1), S55-S76.

https://doi.org/10.1123/jpah.3.s 1.s55

Heffron, R. (2014). Leadership and policy delivery in regeneration practice in a time of austerity. Journal of Urban Regeneration \& Renewal, 7(3), 243-250.

Irazábal, C. (2017). City Making and Urban Governance in the Americas: Curitiba and Portland. Routledge.

Irvine, J. (2008). A Changing Climate for Urban Design: An Examination of the New Zealand Regulatory Approach. New Zealand Journal of Environmental Law, 12, 277. https://heinonline.org/HOL/Page ?handle=hein.journals/nzjel12\&id $=281 \&$ div $=\&$ collection $=$

John, P., \& Cole, A. (1999). Political leadership in the new urban governance: Britain and France compared. Local Government Studies, 25(4), 98-115. https://doi.org/10.1080/030039 39908433969

Kearns, A., \& Paddison, R. (2000). New Challenges for Urban Governance. Urban Studies, 37(5-6), 845-850. https://doi.org/10.1080/004209 80050011118

Lakshman, C. (2012). Structured content analysis in leadership research: A new method for international contexts. Leadership \& Organization Development Journal, 33(5), 477-493. https://doi.org/10.1108/014377 31211241265

Madanipour, A. (2006). Roles and Challenges of Urban Design. Journal of Urban Design, 11(2), 173-193.

https://doi.org/10.1080/135748 00600644035

Martin, J., \& Simons, R. (2002). Managing Competing Values: Leadership Styles of Mayors and CEOs. Australian Journal of Public 
Administration, 61(3), 65-75. https://doi.org/10.1111/14678500.00285

Mullins, D., \& Bortel, G. van. (2010). Neighbourhood regeneration and place leadership: Lessons from Groningen and Birmingham. Policy Studies, 31(4), 413-428. https://doi.org/10.1080/014428 71003723325

Purbani, K. (2017). Collaborative planning for city development. A perspective from a city planner. Scientific Review Engineering and Environmental Sciences, 2017(vol.26(1)), 136-147. https://doi.org/10.22630/PNIKS. 2017.26.1.12

Rondinelli, D. A., \& Heffron, J. M. (2009). Leadership for Development: What Globalization Demands of Leaders Fighting for Change. Kumarian Press.

Satterthwaite, D. (2009). Editorial: What role for mayors in good city governance? Environment and Urbanization, 21(1), 3-17. https://doi.org/10.1177/095624 7809103505

Steele, W., \& MacCallum, D. (2014). Australian environmental governance and environmental planning procedures. In J. Byrne, N. Sipe, \& J. Dodson (Eds.), Australian Environmental Planning: Challenges and Future Prospects (1st ed., pp. 49-68). Routledge.

Sweeting, D. (2002). Leadership in Urban Governance: The Mayor of London. Local Government Studies, 28(1), 3-3. https://doi.org/10.1080/714004 134

\section{Author(s) contribution}

Faruq Ibnul Haqi contributed to the research concepts preparation, methodologies, investigations, data analysis, visualization. articles drafting and revisions.

Sri Tuntung Pandangwati contribute to the research concepts preparation and literature reviews, data analysis, of article drafts preaparation and validation 